\title{
Millennials'choices in applying digital techniques for tourism purposes
}

\author{
Codruța Adina BĂLTESCU \\ Transilvania University of Brașov, Brașov, Romania \\ codruta.baltescu@unitbv.ro
}

\begin{abstract}
Digitisation is a constant of contemporary life. The generation most accustomed to using online resources and electronic devices is that of Millennials. Considered a rebel generation, Millennials have strong believes and values, are deeply connected to their peers and to the world, and also, important users of electronic devices and online sources for entertainment purposes. Although considered a labor industry, tourism is increasingly adapting to the new trends of the activity's digitisationThe paper presents two types of researches. The first one aims to emphasize Millennials' habits in the tourism consumption. In this respect, the results of a qualitative research were presented. The second objective highlights which are the most famous museums in Romania and evaluates the 11 selected museums based on specific criteria on their digitisation progress. At the same time, the 11 museums were assessed based on the number of reviews and the average scores recorded on Google and TripAdvisor platforms. The results obtained show a little interest of the millennial consumers in applying digital techniques for visiting tourist attractions, mainly museums. They majority considers virtual visits as temporary habits, and only as a consequence of crisis situations. On the other hand, the process of Romanian museums' digitisation is in progress, managerial transformations being valuable. The main contribution of the paper consists in the $x$-ray performed on the digitisation process of the Romanian museums.
\end{abstract}

Keywords: Millennials, digitisation, tourism behavior, tourism destinations, museums.

\section{Introduction}

Generational theory is neither new nor uncontroversial. Taking into account the fact that "there is no absolute consensus as to the exact calendar years constituting each generation", Millennials or Generation Y were born between 1982 and 2005 (Howe \& Strauss, 2007), and are the present leaders, managers and also important consumers for tourism services (Benckendorff et al., 2010, p. 2).The differences between the generations are widely accepted, and people's inclusion into a certain generation,largely influence their behavior and lifestyle.

Millennials are more than three times the size of the previous Generation X (Valentine \& Powers, 2013, p. 597), their influence in business management and marketing being enormous. Millennialsrepresent a real force to shape social and economic dynamics, being the first generation accustomed from childhood with digital communication devices, reflecting a rich experience with internet communication (Gorman et al., 2004). Public cyberspace and use of information are pillars for Millennials' behavior, and they expect nonstop interaction with their peers, developing new standards for social networking, especially the online social interaction (Howe \& Strauss, 2007; Nusair et al., 2013). For the tourism industry, Millennialsgenerate a substantial market, gathering information about their travel characteristics and attitudes being a prerequisite for any tourism manager (Benckendorff et al., 2010).

The paper emphasizes the importance of applying digital techniques in the tourism industry. Two main objectives are the core of this article. The first of the objectives aims to analyze the habits of millennial consumers on the use of digital techniques in tourism consumption. To this end, a qualitative research was conducted on a sample of 42 students and

DOI: $10.2478 /$ picbe-2021-0025

(C) 2021 C. A. Băltescu, published by Sciendo.

This work is licensed under the Creative Commons Attribution 4.0 License. 
master students form the Transilvania University of Braşov. The second objective is represented by the analysis of the most famous museums in Romania. A number of 11 museums were selected and based on specific criteria their digital performances were evaluated. Finally, the hierarchy of these museums based on the reviews recorded by visitors on Google and TripAdvisor platforms was discussed.

\section{Literature review}

Howe and Strauss (2000, pp. 7-10) consider Millennials as a rebel generation, butin a good sense, they are optimists, describing themselves as "happy, confident and positive", cooperative and good team players, with a deep believe in their own collective power, rule followers, smart and also prone to progress.

The Millennials' beliefs and values are fun and lifestyle driven, their main motivations are self-discovery and relationships, tend to rely on friends advices and show little brand loyalty, and are influenced, at a great extent, by viral communication in which they are deeply involved (Benckendorff et al., 2010, p. 4). This generation's members understand the benefits of long-term learning, but are generally averse to reading, they do not consult the e-mails on a regular basis, and show less appreciation to traditional messages or texts, considering easier to communicate through visual messages (Valentine \& Powers, 2013; Viswanathan \& Jain, 2013). They and Hanzaee \& Aghasibeig (2010) argue the "perfectionist' side of Millennials, showing a predominant choice for perfect, high-quality products. Millennials are trustful, important supporters for social causes, tolerant and also appreciative with companies' sustainable responses (Furlow, 2011).

The analysis of Millennials' media habits allow marketers to understand how to reach, convince and create loyalty among these very different consumers. Being educated and selfconscious, they cannot be influenced by traditional media as previous generations, most marketers considering them an enigma for which it is imperative to create new communication techniques (Valentine \& Powers, 2013). Moreover, Millennials do not take for granted information communicated via Internet, both trust and securityperceptions playing a significant influence on their intentions as consumers (McLaughlin et al., 2020).

As "digital natives", Millenials display a huge confidence in using new internet technologies, technologies being perceived as essential in their lives (Prensky, 2001; Selwyn, 2009). Moore (2012) highlighted that compared to previous Generation X members, millennial consumers are more integrated in social media in their daily lives, and access online resources for both utilitarian and entertainment purposes. At the same time, it is important to notice the fact that as consumers, they are influenced, at a great extent, by their friends in different products' and brand's evaluation, for several categories such as electronics, fashion, mobile devices or tourism services (Viswanathan\& Jain, 2013). They show great attraction to a range of media, and prefer blogs, reviews, and social networks and for such specific reasons these are the main connecting means which are used by retailers to reach millennial consumers (Valentine \& Powers, 2013). Mainstream media and television are communication channels almost ignored by Millennials, their resilience towards advertisements transmitted through these traditional media being well analyzed (Valentine \& Powers, 2013, p. 599). In order to perfect the analysis on the information sources, Swinarski et al., (2010) highlighted that Millennials are also influenced by other "socialization agents" besides media, which are parents, school, peers, and their personal experience. 
Another important issue to be analyzed refers to Millennials' habits to spend their earnings. Martin \& Turley (2004) highlighted an important feature of their financial behavior, reflected in "spending now" and "saving later" culture.Millennials also have a short-term view towards their financial goals, focusing, in general, more on the short term than the long term, in every respect (Viswanathan \& Jain, 2013, p. 486). At the same time, they carefully watch the spendings, but show willingness to pay high prices for best quality products which they believe worth the money (Hanzaee \& Aghasibeig, 2010, p. 174). As for tourism products, it was demonstrated the same price sensitivity, Millennials do not hesitate to buy expensive tourism products and services, their need for socialization and experiences being far more important (Fyall et al., 2017).

A constant of the last years has been the continuous development of sales for tourism products on the internet. Electronic sources are used both for information, search for solutions, making comparisons, actual acquisition, as well as for further communication on the consumer experience. Millennials, which are often referred as the online generation, are constant econsumers, and able to process e-information faster than the previous generations (Purani et al., 2019). On the other hand, tourism websites are specifically designed to generate commercial and financial benefits by influencing consumers' decisions, promoting tourism products, creating and retaining customers (Sugandini et al., 2018).Having a great desire for active involvement and engagement, Millennials are attracted not mainly by the physical location, instead they appreciate more the attraction experience, as they seek for adventure and fun (Benckendorff et al., 2010).Millennials' tourism consumption is dependent on the degree of enjoyment and pleasure, considered as essential factors for their attitudes and emotional responses. The solutions they prefer, for transport and accommodation services, are selected, at a great extent, through collaborative consumption, which is more and more accentuated for the tourism industry, and especially among millennial consumers (Hwang \& Griffiths, 2017).

Millennial consumers are also innovative consumers and show the "desire to purchase cool products to reflect their personality,individuality, and self-identity" (Noh et al., 2014, p. 277). Translated to the tourism sector, the more innovative tourism managers are, the more valued they will be by millennial tourists (Bogicevic et al., 2021).Tourist attractions' visits ofMillennials are characterized, yet again, by specific elements which explain their travel behavior. They show important "desire to practice longer dwell times whilstvisiting the various elements of the attraction, with short visitspredominating and few opportunities to extend the visit" (Fyall et al., 2017, p.41).

Innovative activities developed by attractions' managers in order to capitalize their cocreation initiatives coupled with different methods of engagement might enhance the travel experience and appreciation of the attraction offer. Also, designing social, online and event spaces with high appeal or "chill-out" zones specifically in museums, are consistent and useful tools in providing the needed facilities for Millennials and fulfilling their visiting experience (Fyall et al., 2017).Museums, which are important cultural and historical attractions, distinguish three main audience segments: market mediators (art critics), casual consumers (museum-goers seeking leisure experiences), and connoisseurs (museum-goers who derive part of their social identity as knowledgeable,engaged consumers) (Noh \& Tolbert, 2019, pp.104-105). Especially for the second group of consumers, without ignoring the others two, museums and most cultural attractions stand out through new and authentic organizational models to attract the younger generation. The main objective of the necessary transformations is defined by digitisation which enables to increase customer value and to create new values. It is obvious that "museums are 
among the many mature institutions thatcurrently find themselves at a crossroads of digital transformation" (Tim et al., 2020, p.10). The major digitisation innovations that are applied, for instance in museums, are the interactive services (in order to increase consumers' power, to create synergies, to customize service consumption, and others), service robots and artificial intelligence services (Alshawaaf \& Lee, 2021).

Providing memorable tourism experiences has been a main focus for many researchers and also tourism practitioners. Loureiro et al., (2020) stated that virtual reality and augmented reality are immersive technologies, the latest technical evolutions, created to enhance tourists' satisfaction. Their applicability is vast. Shops, hotels, restaurants and destinations are important beneficiaries of these new technologies. The revolution estimated as a consequence of introducing and applying them will shape the future for the tourism industry and, as studies show, such instruments are used mainly by youngest generations (Loureiro et al., 2020, p. 2).

\section{Methodology}

The first objective of the article consists in identifying Millennials' commitment in using digital means to acquire and consume tourism products. The chosen research method was the qualitative marketing research based on the semi-directional interview method. For this purpose, a number of 42 students and master students from the Faculty of Economic Sciences and Business Administration, Transilvania University of Brașov were interviewed. The research objectives are the following:

- Identification of respondents' choices on the types of tourism destinations were they prefer to spend their holidays;

- The assessment on the use of digital means for tourism consumption.

The interview guide used was based on two discussion topics, each one ensuring the fulfillment of the research objectives. The interview was carried out on the university's platform and the duration had an average of 15 minutes. The interviews were afterwards transcribed. The analysis was organized according to the content analysis method, as it enabled to breakdown the content of the interviews into manageable units which later could be analyzed and classified into categories (Mayring, 2000). The sample is not representative, respondents being selected from only one university and also, from a limited age range, i.e. between 20 to 27 years old. Still, the results could contribute to deepen knowledge on Millennials' tourism habits. The participation in the research was voluntarily and the sample included 30 female respondents $(71.4 \%)$ and 12 male respondents (28.6\%). The in-depth interview was conducted in November 2020.

The second objective of the article consists in highlighting the actual stage of introducing new digital techniques for the consumption of tourist services within cultural tourist attractions in our country. To accomplish this objective, the most well-known museums from Romania were selected. Two types of information were used in this respect. The first selection criteria consisted in consulting the website of the Romanian Ministry of Culture (Ministerul Culturii, 2021), which allows access to annual activity reports for 34 of the most important cultural institutions in our country, of which 13 are museums. It is worth mentioning that after consulting these reports it did not emerge which was the annual number of visitors that would allow further statistical evaluations. The only figures offered for public information concerned the number of participants in various exhibitions and events organized by these cultural institutions. In the absence of official information, a second selection criteria was applied, namely the number of evaluations performed online by visitors on Googleand Trip Advisor, and the average ratings based on the 
online reviews. Beside the list, the author added one museum, i.e. The National Museum of Art of Romania, with many reviews (6137 reviews) registered on the TripAdvisor platform (Table 1).

Table 1. Romanian Museums included in the Romanian Ministry of Culture list

\begin{tabular}{|c|c|c|c|c|c|}
\hline Museums & Location & $\begin{array}{l}\text { Number } \\
\text { of } \\
\text { reviews } \\
\text { on } \\
\text { Google } \\
\end{array}$ & $\begin{array}{l}\text { Google } \\
\text { average } \\
\text { rating }\end{array}$ & $\begin{array}{l}\text { Number of } \\
\text { reviews on } \\
\text { TripAdvisor }\end{array}$ & $\begin{array}{l}\text { TripAdvisor } \\
\text { average } \\
\text { rating }\end{array}$ \\
\hline $\begin{array}{l}\text { The National History Museum of } \\
\text { Romania }\end{array}$ & Bucharest & 3712 & 4.3 & 372 & 3.5 \\
\hline MuzeulNational al ȚăranuluiRomân & Bucharest & 7 & 4.4 & 400 & 4.0 \\
\hline $\begin{array}{l}\text { Muzeul de Artă "VasileGrigore - } \\
\text { pictorșicolecționar" }\end{array}$ & Bucharest & 57 & 4.6 & 2 & 4.0 \\
\hline The Village Museum "DimitrieGusti" & Bucharest & 6207 & 4.6 & 4353 & 4.5 \\
\hline National Museum "George Enescu" & Bucharest & 1070 & 4.4 & 218 & 4.0 \\
\hline National Museum of Contemporary Art & Bucharest & 1085 & 4.3 & 87 & 3.5 \\
\hline MuzeulNațional al HărțilorșiCărțiiVechi & Bucharest & 515 & 4.6 & 28 & 5.0 \\
\hline $\begin{array}{l}\text { GrigorieAntipa National Museum of } \\
\text { Natural History }\end{array}$ & Bucharest & 11049 & 4.7 & 771 & 4.5 \\
\hline ComplexulNaționalMuzeal Moldova & Iași & 44 & 4.5 & 562 & 4.5 \\
\hline $\begin{array}{l}\text { MuzeulNațional de Istorie a } \\
\text { Transilvaniei }\end{array}$ & $\begin{array}{l}\text { Cluj- } \\
\text { Napoca }\end{array}$ & 526 & 4.1 & 23 & 3.0 \\
\hline Brukenthal National Museum & Sibiu & 553 & 4.5 & 382 & 4.0 \\
\hline MuzeulNațional "Peleș" & Sinaia & 39116 & 4.7 & 4521 & 4.5 \\
\hline $\begin{array}{l}\text { National Museum of Eastern } \\
\text { Carpathians }\end{array}$ & $\begin{array}{l}\text { Sfântu- } \\
\text { Gheorghe } \\
\text { Miercurea- } \\
\text { Ciuc } \\
\text { Araci, } \\
\text { Covasna } \\
\text { County }\end{array}$ & 35 & 4.7 & - & - \\
\hline $\begin{array}{l}\text { The National Museum of Art of } \\
\text { Romania }\end{array}$ & Bucharest & 6137 & 4.6 & 647 & 4.0 \\
\hline
\end{tabular}

Source: Authors' own research.

From the museums included in Table 1, the author selected only the museums which registered more than 500 reviews on at least one of the two online platforms. The final list included 11 museums, the three museums which did not meet the established criteria beingMuzeulNațional al ȚăranuluiRomân, Muzeul de Artă "VasileGrigore - pictorșicolecționar" and the National Museum of Eastern Carpathians.

\section{Results and discussions}

The results of the qualitative research were structured on discussion topics which are based on the main objectives of the research. The method of content analysis was used, aiming to extract from the content of discussion all the relevant information with the final aim to reach the research objectives.

Objective 1 - Identification of respondents' choices on the types of tourism destinations were they prefer to spend their holidays.

The respondents selected the tourism destinations where they prefer to spend their holidays. They had the opportunity to choose from 8 options included in the interview guide and 
one option was added allowing respondents to give a free answer. The most frequently chosen type of tourism destinations were the seaside destinations, which were chosen by 38 of the respondents. In the following order, the other types of tourism destinations indicated were: urban destinations (37 responses), mountain destinations (29 responses), destinations appropriate for adventure tourism (21 responses), destinations well known for events and festivals (16 responses), sport destinations (15 responses), religious destinations (8 responses), and rural destinations (7 responses). None of the respondents did offer a free answer to indicate another type of tourism destination they prefer.

The respondents also indicated two of the tourism destinations they prefer most.Only seven out of the eight previous destinations were chosen, namely seaside destinations, urban destinations, mountain destinations, adventure destinations, rural destinations, sport destinations and festival destinations. The most common chosen destinations were the urban ones $(31,3 \%)$, followed by the seaside destinations (27,7\%), mountain destinations (21,7\%), adventure destinations $(9,6 \%)$, festival destinations $(6 \%)$, sport destinations $(2,4 \%)$ and rural destinations $(1,3 \%)$.

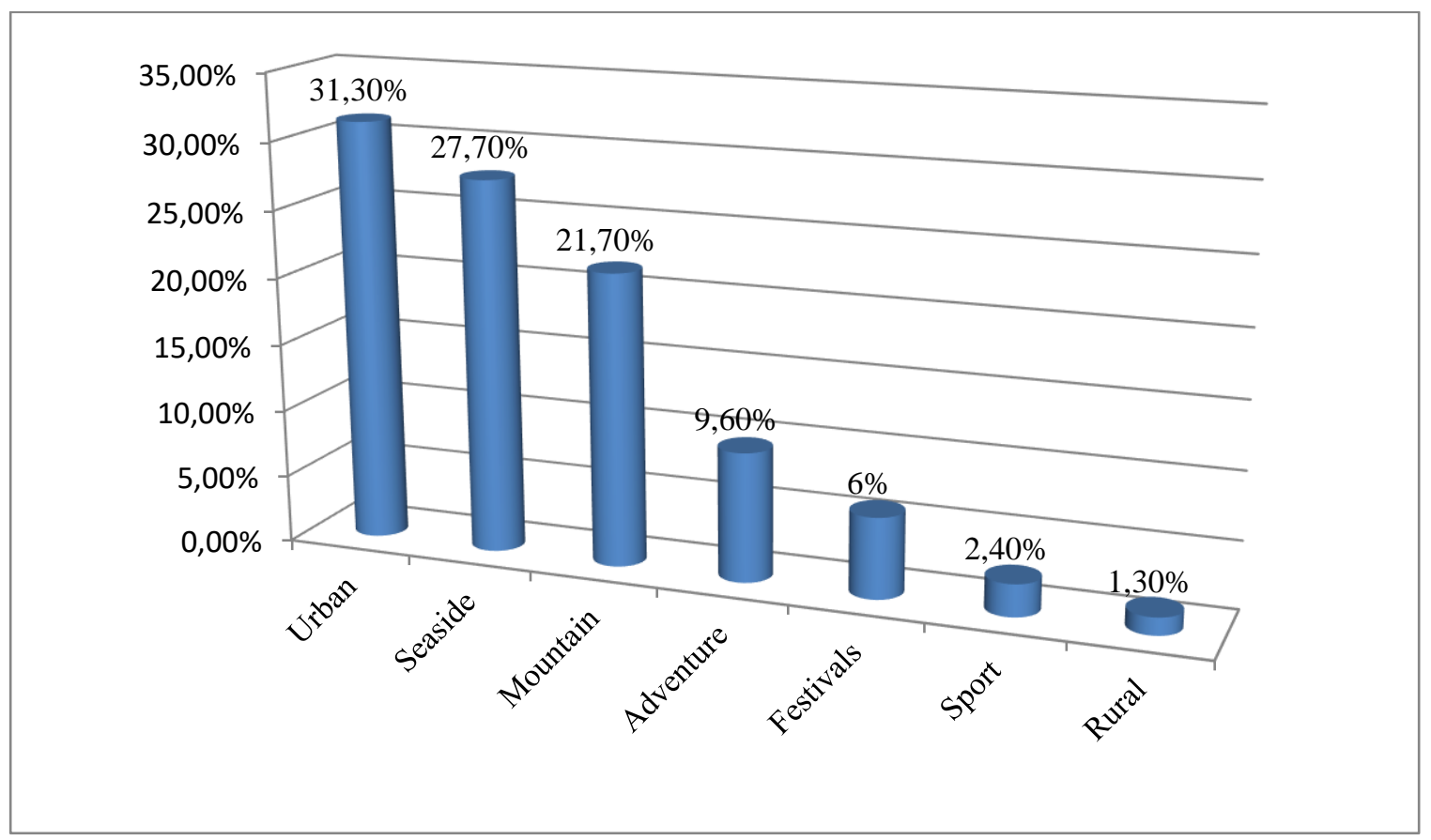

Figure 1. The tourism destinations most chosen for holidays

Source: Author own research.

Objective 2 - The assessment on the use of digital means for tourism consumption.

A first topic of discussion on this subject revealed respondents' experience generated by online and virtual visits of tourist attractions, mainly museums. They indicated that they find this experience as highly interesting for spending leisure time (19,6\% out of the total responses), as a good replacement of the physical visit $(12,5 \%)$, a cheap way to visit a tourist attraction $(16,1 \%)$, whilst the majority of responses, more than a half out of them $(51,8 \%)$ indicated that virtual visits are only temporary, caused by the pandemic situation or other crises and does not cancel the actual visit. 
The respondents also indicated if they recently performed virtual visits for tourist attractions. Only 3 of the respondents $(2,4 \%)$ highlighted that they find time and interest in discovering virtual visits as means for spending their free time. The tourist attractions they visited through digital techniques were the Botanical Garden from Cluj-Napoca, Italy's region Toscana, while one of the respondents indicated that he is a big fan of virtual visits, many tourism destinations and tourist attractions being on his list, such as Versailles Palace, Meteora- Greece, City of Petra in Jordan and many more. These respondents also stated their willingness to visit those attractions also in real-life. The finding is similar to other studies, as it becomes obvious that virtual reality motivates consumers to visit the attraction in real-life (Bogicevic et al., 2021, p. 7).

The last discussion topic aimed their appreciation for urban visits accompanied by virtual tourist guides, different smart-phone applications, augmented reality and others. The majority indicated on a scale from 1 (very good experience) to 5 (very poor experience), that the find such an experience nor good nor bad (18 responses, $43 \%)$. 9 out of the respondents considered such an experience as a good one (21\%), 8 respondents considered it as a poor experience (19\%), 5 respondents have a very good opinion of such an experience (12\%), and 2 respondents indicated their very poor opinion on this matter (5\%). They also stated they would prefer using these digital means for traveling, only in the lack of choices, and that nothing compares with the traditional and humoroustouring guiding.

In order to fulfill the analysis on the digital means used to visit museums, the 11 Romanian museums selected on the above mentioned criteria, were assessed in order to highlight the digitisation techniques implemented in the visiting process. Information was obtained by consulting their official websites. The elements considered essential to identify the digitization level of these institutions were the following: (Alshawaaf \& Lee, 2021; Stylianiet al., 2009; Tim et al., 2020) (a) interaction with visitors through social media - SM;(b) virtual visits - VV; (c) virtual exhibitions - VE; (d) digital projects for specific collections - DP; (e) online membership allowing exclusive benefits - OM; (f) online shop - OS; (g) IoT technologies afford full visibility of physicalobjects - IoT; (h) incorporating interactive elements into museum's services - IE (Table 2).

Table 2. Digitisation experience in Romanian museums

\begin{tabular}{|l|l|l|l|l|l|l|l|l|}
\hline Museum & SM & VV & VE & DP & OM & OS & IoT & IE \\
\hline The National History Museum of Romania & Yes & Yes & Yes & No & No & Yes & No & Yes \\
\hline The Village Museum "DimitrieGusti" & Yes & Yes & No & No & No & No & No & Yes \\
\hline National Museum "George Enescu" & Yes & No & No & Yes & No & No & No & Yes \\
\hline National Museum of Contemporary Art & Yes & No & No & Yes & No & No & No & No \\
\hline MuzeulNațional al HărțilorșiCărțiiVechi & Yes & Yes & No & Yes & No & Yes & Yes & Yes \\
\hline $\begin{array}{l}\text { GrigorieAntipa National Museum of } \\
\text { Natural History }\end{array}$ & Yes & Yes & No & No & Yes & No & No & Yes \\
\hline ComplexulNaționalMuzeal Moldova & Yes & No & No & No & No & No & No & Yes \\
\hline MuzeulNațional de Istorie a Transilvaniei & Yes & Yes & No & Yes & No & No & No & Yes \\
\hline Brukenthal National Museum & Yes & No & No & Yes & No & No & No & Yes \\
\hline MuzeulNațional "Peleș" & Yes & No & No & Yes & No & Yes & No & Yes \\
\hline The National Museum of Art of Romania & Yes & Yes & No & Yes & No & No & Yes & Yes \\
\hline
\end{tabular}

The assessments of the digitisation techniques implemented within the 11 analyzed Romanian museums highlighted that important steps are being taken in the direction of adapting 
to the requirements of the modern visitors, accustomed to use digital technology. None of the museums fully met all of the eight criteria. In the attempt to make a list of Romanian museums that introduced digitisation means to increase the visiting experience and interaction with the virtual visitor, the most updated museum is MuzeulNaţional al HărțilorșiCărțiiVechi, which met six of the eight criteria.It is followed by the National History Museum of Romania and the National Museum of Art of Romania which have implemented five of the evaluated digitization criteria. In this hierarchy, next are the GrigorieAntipa National Museum of Natural History, the National Museum of History of Transylvania and the Peles National Museum which implementedfour of the analyzed criteria.The Village Museum "DimitrieGusti", the National Museum "George Enescu", the National Museum of Contemporary Art, and the Brukenthal National Museum stand out next, as three of the digitization criteria were implemented, and on the last places in this hierarchy, with only $25 \%$ of the digitization criteria met, are placed ComplexulNaţionalMuzeal Moldova and the National Museum of Contemporary Art.

The assessed museums develop interactions with visitors through social media channels, being the only criteria fulfilled by all the 11 museums. Virtual visits are implemented by six of the museums, while digital projects for specific collections are implemented by a number of seven museums. The less fulfilled criteria are online membership which enable enhancing interactions with virtual visitors, which is applied only by GrigorieAntipa National Museum of Natural History, and the IoT technologies to afford full visibility of physical objects, implemented only by two museums, namely MuzeulNațional al HărţilorșiCărțiiVechiand The National Museum of Art of Romania.

Another aspect is the popularity of these museums, analysis supported by the number of reviews both on Google and TripAdvisor. According to Google, the most visited Romanian museum is MuzeulNaţional "Peleș" with an impressive number of reviews, i.e. 39116 reviews. The second Romanian museum in this hierarchy is Grigorie Antipa National Museum of Natural History, with 11049 reviews, followed by the Village Museum "Dimitrie Gusti" with 6207 reviews, The National Museum of Art of Romania with 6137 reviews and The National History Museum of Romania with 3712 reviews. The other six museums met a much smaller number of reviews, generally less than 1000 reviews. The same interpretation is valid when analyzing Trip Advisors' number of reviews.

As for the average ratings, Muzeul Național al Hărților și Cărții Vechi obtained the highest scores, i.e. the maximum 5.0 on TripAdvisor and 4.7 on Google. One of the reasons for the highest notes recorded by Muzeul Național al Hărților și Cărții Vechi is, undoubtedly, the increased digitisation progress of the museum. The conclusion is in line with other studies on the same topic (Alshawaaf \& Lee, 2021;Carrozzino, \& Bergamasco, 2010).

The Village Museum "Dimitrie Gusti" and Grigorie Antipa National Museum of Natural History are second in line in th ehierarchy, both museums recorded high average scores, from both data sources. The museum with the lowest average notes is Muzeul National de Istorie a Transilvaniei from Cluj-Napoca, evaluated with 3.0 points on TripAdvisor and 4.1 points on Google.

\section{Conclusion}

Digitisation is the future in the tourism industry. New generations are arising, and for all of them online and digital applications are parts of everyday life. The tourism industry, which is wellknown as a "labor industry" (Minciu, 2004) adapts itself to these new, emerging digital techniques. 
The paper highlightes two aspects. On the one hand, based on the research conducted among the Millennials' representatives from the Transilvania University of Brassov, it was revealed that the potential visitors do not have a real desire to use digital means for tourism consumption. They prefer, instead, the more traditional means for visiting, mainly for the tourist attractions. At the same time, when asked about their most preferred tourism destinations, the urban destinations were the first nominated. And, it is well known, that visiting tourist attractions is an essential tourist activity in a city. On the other hand, the article presented an assessment of the most well-known museums in Romania. The results obtained emphasized the differences between these cultural institutions on their digitization progress. The museum which implemented these applications at the highest degree gets the highest scores from the visitors.

Increasing the role of cultural institutions in the overall visiting experience will also depend on adapting to the requirements of the younger generations. As museums increase the digitisation performances, visitors will understand the benefits provided and will perceive, for example, visiting a museum as a very enjoyable and pleasant activity, not just an instructive and boring one. This is the trend that should be followed (Benckendorff et al., 2010; Howe and Strauss, 2000).

The major limitations of the present study are related to the samples used in the research. Results obtained in the qualitative research cannot be extrapolated and also, the analyzed museums represent only a small part of the Romanian cultural institutions. Nevertheless, the study makes an x-ray of the performances obtained in the digitization process by the most famous museums in Romania, and also highlights that the managerial teams of museums must view the reviews, interpret and adapt the business performance according to the reviews recorded online by their visitors.

\section{References}

Alshawaaf, N., \& Lee, S. H., (2021). Business model innovation through digitisation in social purpose organisations: A comparative analysis of Tate Modern and Pompidou Centre Nasser, Journal of Business Research, 125, 597-608.

Benckendorff, P., Moscardo, G., \& Pendergast, D. (2010), Tourism and Generation Y. Oxfordshire: CAB International.

Bogicevic, V., Liu, S. Q., Seo, S., Kandampully, J., \& Rudd, N. A. (2021). Virtual reality is so cool! How technology innovativeness shapes consumerresponses to service preview modes, International Journal of Hospitality Management, 93, 102806, 1-10.

Carrozzino, M., \& Bergamasco, M. (2010). Beyond virtual museums: Experiencing immersive virtual reality in real museums, Journal of Cultural Heritage, 11(4), 452-458.

Furlow, N. E. (2011). "Find us on Facebook: how cause marketing has embraced social media", Journal of Marketing Development and Competitiveness, 5(6), 61-64.

Fyall, A., Leask, A., Barron, P., \& Ladkin, A. (2017). Managing Asian attractions, Generation Y and face, Journal of Hospitality and Tourism Management, 32, 35-44.

Gorman, P., Nelson, T., \& Glassman, A. (2004). The Millenial Generation: A Strategic Opportunity, Organizational Analysis, 12(3), 255-270.

Hanzaee, K. H., \& Aghasibeig, S. (2010). Iranian Generation Y female market segmentation, Journal of Islamic Marketing, 1(2), 165-176.

Howe, N., \& Strauss, W. (2000). Millennials Rising. The Next Great Generation, New York, Vintage Books. 
Howe, N., \& Strauss, W. (2007). The Next 20 Years: How Customer and Workforce Attitudes Will Evolve. Harvard Business Review (July-August 2007). Retrieved from https://hbr .org/2007/07/the-next-20-years-how-customer-and-workforce-attitudes-will-evolve.

Hwang, J. \& Griffiths, M. A. (2017). Share more, drive less: Millennials value perception and behavioral intent in using collaborative consumption services, Journal of Consumer Marketing, 34(2), 132-146.

Loureiro, S. M. C., Guerreiro, J., \& Ali, F. (2020). 20 years of research on virtual reality and augmented reality in tourismcontext: A text-mining approach, Tourism Management, 77, 104028, 1-21.

Martin, C. A., \& Turley, L. W. (2004). Malls and consumption motivation: An exploratory examination of older Generation Y consumers, International Journal of Retail \& Distribution Management, 32(10), 464-475.

Mayring, P. (2000). Qualitative Content Analysis, Forum Qualitative Social Research, 1(2). Retrieved from https://www.qualitative-research.net/index.php/fqs/article/view/1089/ 2385.

McLaughlin, C., McCauley, L. B., Prentice, G., Verner, E.-J., \& Loane, S. (2020). Gender differences using online auctions within a generation $\mathrm{Y}$ sample: An application of the Theory of Planned Behaviour, Journal of Retailing and Consumer Services, 56, 102181, $1-13$.

Minciu, R. (2004). Economia Turismului (2 ${ }^{\text {nd }}$ ed.), București, Editura Uranus.

Ministerul Culturii (2021). Evaluări anuale pentru anul 2019. Retrieved from http://www.cultura .ro/rapoarte-de-activitate.

Moore, M. (2012). Interactive media usage among millennial consumers, Journal of Consumer Marketing, 29(6), 436-444.

Noh, M., Runyan, R., \& Mosier, J. (2014). Young consumers' innovativeness and hedonic/ utilitarian cool attitudes, International Journal of Retail \& Distribution Management, 42(4), 267-280.

Noh, S., \& Tolbert, P. S. (2019). Organizational identities of U.S. art museums and audience reactions, Poetics, 72, 94-107.

Nusair, K. K., Bilgihan, A., \& Okumus, F. (2013). The role of online social network travel websites in creating social interaction for Gen $\mathrm{Y}$ travellers, International Journal of Tourism Research, 15(5), 458-472.

Prensky, M., (2001). Digital natives, digital immigrants. On the Horizon, 9(5), 1-6.

Purani, K., Kumar, D. S., \& Sahadev, S. (2019). e-Loyalty among millennials: Personal characteristics and social influences, Journal of Retailing and Consumer Services, 48, 215-223.

Selwyn, N., (2009). The digital native: myth and reality, Aslib Proceedings: New Information Perspectives, 61(4), 364-379.

Swinarski, M., Parente, D., \&Noce, K. (2010). A study of gender differences with respect to internet socialization of adolescents, Journal of Business \& Economics Research, 8(6), 23-30.

Styliani, S., Fotis, L., Kostas, K., \& Petros, P. (2009). Virtual museums, a survey and some issues for consideration, Journal of Cultural Heritage, 10, 520-528.

Sugandini, D., Feriyanto, N., Yuliansyah, Y., Sukwadi, R., \& Uii, M. (2018). Web quality, satisfaction, trust and its effects on government website loyalty, International Journal for Quality Research, 12(4), 885-904. 
Tim, Y., Ouyang, T., \& Zeng, D. (2020). Back to the future: Actualizing technology affordances to transform Emperor Qin's terracotta warriors Museum, Information \& Management, 57, $103271,1-13$.

Valentine, D. B., \& Powers, T. L. (2013). Generation Y values and lifestyle segments, Journal of Consumer Marketing, 30(7), 597-606.

Viswanathan, V., \& Jain, V. (2013). A dual-system approach to understanding "generation Y" decision making, Journal of Consumer Marketing, 30(6), 484-492. 